\title{
THE DEVELOPMENT OF EARLY ORGAN FAILURE IN NECROTISING ACUTE PANCREATITIS
}

\author{
Vinnik Y.S. ${ }^{1}$, Dunaevskaya S.S. ${ }^{1}$, Antufrieva D.A. ${ }^{1}$, Deulina V.V. ${ }^{1}$ \\ ${ }^{1}$ SBEI HPE KrasSMU named after prof. V.F. Voyno- Jaseneckiy» Russian Ministry of Health, Krasnoyarsk, e-mail: \\ Vikto-potapenk@yandex.ru
}

Aims.

The study was aimed at the correlation of the development of early organ failure with the necrotising lesion of the pancreas and the prevalence of peripancreatic infiltration.

Materials and methods.

The treatment data of 1,550 patients with acute pancreatitis were analysed. The pancreatic lesion characteristics were evaluated by dynamic ultrasound and CT angiography in the third week of the disease. The conclusion on the presence of signs of organ failure was based on the international guidelines (more than 2 points on the SOFA scale).

Results.

In $85.61 \%$, acute pancreatitis was not accompanied by the development of necrotic lesion of the pancreas. In $\mathbf{8 8 . 9 9 \%}$ of cases of interstitial oedema of the pancreas, there was no peripancreatic infiltration. The formation of peripancreatic infiltration in the absence of symptoms of necrotising lesion of the pancreas is a poor prognostic sign. A microfocal lesion was observed in $7.48 \%$ of patients, in these, infiltration of up to 3 regions of the retroperitoneal cellular tissue was detected in $42.25 \%$ of cases, and of 4 to 6 regions - in 27.59\%. Macrofocal necrosis was noted in $5.74 \%$ of them, and in $40.44 \%$ of cases, was accompanied by involvement of 4 to 6 regions of the cellular tissue in the pathological process. Subtotal lesion in less than $1 \%$ of cases was accompanied by a massive infiltration of the cellular tissue, 7 or more anatomical regions in $46.15 \%$. Most often, complications on the part of cardiovascular system developed in phase I $\mathbf{- 2 8 . 0 8 \%}$ of severe acute pancreatitis. The development of multiple organ failure accompanies $48.82 \%$ of patients with severe course of the disease. The development of organ failure was not detected in interstitial oedema of the pancreas. Microfocal lesion was accompanied by complications in $\mathbf{4 1 . 3 8 \%}$ of cases, while macrofocal - in $92.13 \%$, and pancreatic damage with more than $50 \%$ of the volume always caused organ dysfunction.

\section{Conclusions.}

The risk of early organ failure in phase $I$ of severe acute pancreatitis increases with a lesion of greater volume of the pancreas involving more than 3 areas of retroperitoneal cellular tissue in the pathological process.

Keywords: acute pancreatitis, organ failure.

\section{INTRODUCTION.}

Early organ failure in patients with necrotizing pancreatitis is an acute issue not only in urgent surgery but also in resuscitation science. Phase I of severe acute pancreatitis (SAP) is characterized by a "mediator hurricane" and is often associated with severe general complications that require complex treatment in the conditions of the intensive care department [1-3]. Patients with SAP have a high rate of lethality. It should be highlighted that $40 \%$ of lethal outcomes result from the development of early organ failure [4-6].

The clinical development of acute pancreatitis reflects the pathological process in the pancreas and retroperitoneum [7-9]. Thus, the evaluation of the extent and depth of the pancreas damage is the primary task in the diagnostics of acute necrotizing pancreatitis as one of the most severe forms of the disease.

The aim of the study was to evaluate the association between the development of early organ failure and the character of the necrotizing process in the pancreas and the extent of peripancreatic infiltrate.

\section{MATERIALS AND METHODS.}

The prospective clinical observation included 1550 patients with acute pancreatitis that were 
treated in the clinical facilities of the Department of General Surgery named after Prof. M.I. Gulman at the Krasnoyarsk State Medical University named after Prof. V.F. Voino-Yasenetskiy of the Ministry of Healthcare of the Russian federation in 2010-2015. All the patients were diagnosed with acute pancreatitis based on the clinical picture, which was verified by the results of laboratory and instrumental studies performed according to the accepted clinical recommendations.

The identification of the form and stage of the pathological process was based on the Atlanta international classification of acute pancreatitis (Atlanta, 1992), in its modification (Kochin, 2012) approved by the International Association of Pancreatologists and the Working Group on the classification of acute pancreatitis of the International Association of Pancreatologists/American Pancreatic Association (2013) and the Russian Association of Surgeons (2014).

The study entry criteria were patients from 18 years old of any sex that were delivered to the inpatient facility by the ambulance service with the diagnosis of acute pancreatitis phase I. The criteria of exclusion were patients with diabetes mellitus and other endocrine, autoimmune, infectious, and oncologic diseases, comorbid cardiovascular pathology, cardiac insufficiency $2 \mathrm{~A}$ and higher, 2 and higher (functional classification by NYHA), allergic reactions and intolerance to contrasting agents in the anamnesis, pregnancy. The criterion for withdrawal was the patient's refusal from participation in the study.

The evaluation of the condition of the pancreas and retroperitoneum was performed with a screening ultrasonic study with Aloka SSD 3500, $3.5 \mathrm{MHz}$ transducer rate. The study was performed at the admission and in the dynamics on Days 7, 14 and 21.

For detailed visualization, patients with suspected acute necrotizing pancreatitis underwent computed angiography with bolus abdominal contrasting with a multispiral 4-layer computed tomographic scanner LightSpeed (General Electric, USA). Computed angiography was performed for all patients who had a verified diagnosis of severe acute pancreatitis (211 patients).

The medical conclusion on the extent of the pathological process and formation of peripancreatic infiltrate was made on Week 3 (Days 14-21). The description of the extent of the peripancreatic process was made by the classification proposed by Titova (1989).

In cases when the results of CT angiography did not agree with the results of the ultrasonic study, the results of CT scanning were used taking into account the clinical picture of the disease and changes in the results of the laboratory tests. In the early period (72 hours from the disease onset), the impairment of tissue perfusion revealed by CT angiography with bolus contrasting indicates a formation of necrotic foci in the pancreas. In the later period, the areas of necrosis do not accumulate the contrasting agent and cannot be revealed by CT scanning. The verification was performed by the Balthazar-Ranson scale.

An increase in the threshold by 2 points by the SOFA scale indicates a dysfunction of the organ system.

In the present study, the general lethality rate was $2.58 \%$ (40 patients). In 24 patients (60\%), 
the lethal outcome resulted from purulo-necrotic complications. In 16 cases (40\%), the lethal outcomes occurred during phase I of acute necrotizing pancreatitis and were caused by severe systemic complications: pancreatogenic shock in 10 cases and development and progressing of early organ failure in 6 cases.

The statistical processing of the data was performed with the software package Statistica 6.1. The obtained results are presented in absolute and relative values. The conclusion on the association between certain symptoms is based on the single-factor correlation analysis of Spearman, Gamma and Kendall's tau coefficients.

The study protocol followed guidelines for experimental investigation with human subjects in accordance with the Declaration of Helsinki and was approved by the ethics committee. Written informed consent was obtained from each patient (or official representative) before the study.

\section{RESULTS.}

In $85.61 \%$ (1327) of patients, acute pancreatitis was not associated with the development of necrotic damage of the pancreas. The visualization showed that the image in the pancreas corresponded to interstitial edema. In $88.99 \%$ (1181) of cases, there was no peripancreatic infiltrate revealed in patients with the development of interstitial edematous pancreatitis. In $11.01 \%$ of cases, interstitial edematous pancreatitis was associated with the presence of retroperitoneal infiltrate. The formation of peripancreatic infiltrate in patients without the signs of necrotizing damage of the pancreas is a prognostically unfavorable sign. The evaluation of the extent of the infiltrate showed that in $10.03 \%$ of cases, up to 3 anatomical areas were involved in the pathological process. Only in $0.69 \%$ (9) of cases, the infiltrate extended to 4-6 areas and, in single cases (4), to 7 and more areas.

Fine-focal damage of the pancreas was observed in $7.48 \%$ of cases (116 patients): in $42.25 \%$ (49) of cases, the infiltrate extended to 3 areas of the retroperitoneal fat, in $27.59 \%$ (32) of cases from 4 to 6 areas. Macrofocal necrosis was revealed in 5.74\% (89) of cases and, in $40.44 \%$ of cases, it was associated with the involvement of 4 to 6 areas of fat tissue in the pathological process. Subtotal damage of the pancreas was diagnosed in $0.84 \%$ (13) of cases and, in $46.15 \%$ of cases; it was associated with peripancreatic infiltrate extending to 7 and more anatomic areas. Total damage of the pancreas was observed in $0.32 \%$ (5) of cases. The involvement of the retroperitoneum fat in the pathological process was revealed in $100 \%$ of cases (Table 1).

Table 1. Dependence between the extent of the disease and the formation of retroperitoneum infiltrate

\begin{tabular}{|l|l|l|l|l|l|}
\hline Extent of pancreas & Total \\
damage & $\begin{array}{l}\text { number of } \\
\text { patients }\end{array}$ & \multicolumn{4}{|l|}{ Formation of retroperitoneum infiltrate } \\
\cline { 3 - 6 } & No & $\begin{array}{l}\text { Up to 3 } \\
\text { areas }\end{array}$ & $\begin{array}{l}4 \text { to } 6 \\
\text { areas }\end{array}$ & $\begin{array}{l}7 \text { and more } \\
\text { areas }\end{array}$ \\
\hline $\begin{array}{l}\text { Interstitial edematous } \\
\text { pancreatitis }\end{array}$ & 1327 & 1181 & 133 & 9 & 4
\end{tabular}




\begin{tabular}{|c|c|c|c|c|c|}
\hline \multirow{2}{*}{$\begin{array}{l}\text { Extent of pancreas } \\
\text { damage }\end{array}$} & \multirow{2}{*}{$\begin{array}{l}\text { Total } \\
\text { number of } \\
\text { patients }\end{array}$} & \multicolumn{4}{|c|}{ Formation of retroperitoneum infiltrate } \\
\hline & & No & $\begin{array}{l}\text { Up to } 3 \\
\text { areas }\end{array}$ & $\begin{array}{l}4 \text { to } 6 \\
\text { areas }\end{array}$ & $\begin{array}{l}7 \text { and more } \\
\text { areas }\end{array}$ \\
\hline & $(85.61 \%)$ & $(88.99 \%)$ & $(10.03 \%)$ & $(0.68 \%)$ & $(0.30 \%)$ \\
\hline $\begin{array}{l}\text { Fine-focal } \\
\text { pancreonecrosis } \\
(\mathrm{V}<30 \%)\end{array}$ & $\begin{array}{l}116 \\
(7.48 \%)\end{array}$ & $\begin{array}{l}23 \\
(19.82 \%)\end{array}$ & $\begin{array}{l}49 \\
(42.25 \%)\end{array}$ & $\begin{array}{l}32 \\
(27.59 \%)\end{array}$ & $\begin{array}{l}12 \\
(10.34 \%)\end{array}$ \\
\hline Macrofocal & 89 & 3 & 31 & 36 & 19 \\
\hline
\end{tabular}




\begin{tabular}{|l|l|l|l|l|l|}
\hline $\begin{array}{l}\text { pancreonecrosis } \\
\text { (V from 30 to 50\%) }\end{array}$ & $(5.74 \%)$ & $(3.37 \%)$ & $(34.83 \%)$ & $(40.44 \%)$ & $(21.35 \%)$ \\
\hline $\begin{array}{l}\text { Subtotal } \\
\text { pancreonecrosis } \\
(\mathrm{V} \text { from 50 to 75\%) }\end{array}$ & $13(0.84 \%)$ & 0 & $3(23.08 \%)$ & $4(30.77 \%)$ & $6(46.15 \%)$ \\
\hline $\begin{array}{l}\text { Total } \\
\text { pancreonecrosis } \\
(\mathrm{V}>75 \%)\end{array}$ & $5(0.32 \%)$ & 0 & 0 & $1(20.00 \%)$ & $4(80.00 \%)$ \\
\hline \begin{tabular}{l} 
Total: \\
\hline
\end{tabular} & $(100 \%)$ & $(77.87 \%)$ & $(13.94 \%)$ & $(5.29 \%)$ & $(2.90 \%)$ \\
\hline
\end{tabular}

Note: $\mathrm{V}$ - extent of the pancreas damage

The evaluation of the extent of pancreas damage revealed a high direct correlation with the volume of peripancreatic infiltrate $(\mathrm{rS}=0.78 ; \mathrm{p}=0.001)$.

Cardiovascular complications in patients with phase I of SAE were registered in $28.08 \%$ (89) of cases. Acute kidney failure was diagnosed in 30.81\% (65) of patients. The development of the signs of acute kidney failure is a predictor of early organ failure. In $28.91 \%$ (61) of patients with SAE, intoxication consciousness disorders developed. Respiratory failure was observed in $20.85 \%$ (44) of cases. The progressing of acute respiratory failure, including in patients on APV, was registered in senior and senile patients. Hepatic failure was observed in $18.01 \%$ of patients (Table 2).

Table 2. The structure of the development of complications in patients with phase I of severe acute pancreatitis (SAP)

\begin{tabular}{|l|l|l|l|}
\hline SAP I phase complications & $\begin{array}{l}\text { Patients with } \\
\text { complications }\end{array}$ & $\begin{array}{l}\text { Total number of } \\
\text { patients }\end{array}$ & $\begin{array}{l}\text { Patients } \\
\text { with SAP }\end{array}$ \\
\hline Acute cardiovascular insufficiency & 89 & $5.74 \%$ & $42.18 \%$ \\
\hline Acute kidney failure & 65 & $4.19 \%$ & $30.81 \%$ \\
\hline Intoxication consciousness disorders & 61 & $3.94 \%$ & $28.91 \%$ \\
\hline Gastrointestinal insufficiency & 63 & $4.06 \%$ & $29.86 \%$ \\
\hline $\begin{array}{l}\text { Acute respiratory failure, including in } \\
\text { patients on artificial pulmonary ventilation }\end{array}$ & 44 & $2.84 \%$ & $\begin{array}{l}20.85 \% \\
\end{array}$ \\
\hline
\end{tabular}




\begin{tabular}{|l|l|l|l|}
\hline Acute hepatic failure & 38 & $2.45 \%$ & $18.01 \%$ \\
\hline Total (n) & 148 & 1550 & 211 \\
\hline
\end{tabular}

The development of early organ failure was observed in $48.82 \%$ (103) of patients with SAE and significantly aggravated the disease prognosis and the development of phase I of SAE. The complications in two organ systems were revealed in $58.11 \%$ (86) of patients, in more than 2 systems - in $11.49 \%$ (17) of cases with SAE. Early organ failure in SAE phase I caused lethal outcome in 18 cases, which was $8.53 \%$ of patients with SAE, $17.48 \%$ of cases of multiorgan failure, and $45 \%$ from the total lethality in the present study. The obtained results agree with the available published data [3; 4].

There were no cases of organ failure revealed in patients with interstitial edematous pancreatitis. Fine-focal damage of the pancreas was associated with complications in $41.38 \%$ of cases, macrofocal - in $92.13 \%$ of cases, and the extent of damage of more than $50 \%$ of the pancreas always caused the development of organ dysfunction (Table 3).

Table 3. Dependence between the extent of the pancreas damage and the development of early organ failure

\begin{tabular}{|l|l|l|}
\hline Pancreas damage & $\mathrm{n}$ & Development of early organ failure \\
\hline Interstitial edematous pancreatitis & 1327 & 0 \\
\hline Fine-focal pancreonecrosis (V < 30\%) & 116 & $48(41.38 \%)$ \\
\hline Macrofocal pancreonecrosis (V from 30 to 50\%) & 89 & $82(92.13 \%)$ \\
\hline Subtotal pancreonecrosis (V from 50 to 75\%) & 13 & $13(100 \%)$ \\
\hline Total pancreonecrosis (V $>75 \%)$ & 5 & $5(100 \%)$ \\
\hline
\end{tabular}

A high direct correlation $(\mathrm{rS}=0.72, \mathrm{p}=0.001)$ was revealed between the extent of the pancreas damage and the development of early organ failure in patients with SAE phase I.

The lack of peripancreatic infiltrate signs in patients with early organ failure was observed only in 3 cases $(0.25 \%)$. When there were 3 and more areas involved in the pathological process, the share of complications was $14.35 \%$ (31). In patients with peripancreatic infiltrate, early organ failure developed in $89.02 \%$ (73) of cases. In patients with 7 and more damaged areas, early organ failure developed in $91.11 \%$ (41) of cases (Table 4). There was a direct correlation between the formation of peripancreatic infiltrate and the development of complications in patients with SAE phase I, $\mathrm{rS}=0.64(\mathrm{p}=0.001)$.

Table 4. Dependence between the volume of peripancreatic infiltrate and development of early 
organ failure

\begin{tabular}{|l|l|l|}
\hline Volume of peripancreatic infiltrate & $\mathrm{n}$ & Early organ failure \\
\hline Without a spread to fat tissue & 1207 & $3(0.25 \%)$ \\
\hline Up to 3 areas affected & 216 & $31(14.35 \%)$ \\
\hline 4 to 6 areas affected & 82 & $73(89.02 \%)$ \\
\hline 7 and more areas affected & 45 & $41(91.11 \%)$ \\
\hline
\end{tabular}

The extent of necrotizing damage of the pancreas and the formation of peripancreatic infiltrate significantly influences the development of acute pancreatitis. There is a direct positive correlation between the development of necrotizing pancreatitis and the formation of peripancreatic infiltrate. In rare cases, the involvement of retroperitoneal fat in the pathological process was not associated with the damage of pancreatic parenchyma. There is a correlation between the volume of the pancreas and the development of early organ failure. A similar association exists between the development of early organ failure and the formation of peripancreatic infiltrate. The development of early organ failure in patients with SAE phase I is associated with the autotoxication caused by the outburst of numerous biologically active substances, proinflammatory mediators and under oxidized metabolites into the bloodstream after the tissue damage. The obtained data is valuable because patients with acute necrotizing pancreatitis often require urgent medical help in the intensive care unit, and the character of the extent of the pathological process to the pancreas and retroperitoneum fat significantly influences the development of severe systemic complications and early organ failure, which is an acute surgical and intensive care issue [9].

\section{CONCLUSIONS.}

The risk of the development of early organ failure in patients with SAE phase I increases in cases of a greater extent of the pancreas damage and the involvement of more than 3 areas of retroperitoneum fat into the pathological process.

\section{FINANCIAL SUPPORT AND SPONSORSHIP}

Nil.

\section{CONFLICTS OF INTEREST}

The authors declare no conflict of interest

\section{SUPPLEMENTARY DATA (DOI)}

\section{REFERENCES}

1. Maiorov V.M., Dundarov Z.A., Podol'skii A.L. Morphological changes in internal organs in acute necrotizing pancreatitis according to autopsy data [Morfologicheskie izmeneniia vnutrennikh organov pri ostrom nekrotiziruiushchem pankreatite po dannym autopsii], Novosti Khirurgii - Novosti Khirurgii, 2010, vol. 18, no 5 pp. 28-36. 
2. Vinnik Iu.S., Bulygin G.V., Dunaevskaia S.S. Effectiveness of glutoxime application in complex treatment of patients with acute pancreatitis [Effektivnost' primeneniia glutoksima v kompleksnom lechenii bol'nykh ostrym pankreatitom]. Siberian medical review - Sibirskoe meditsinskoe obozrenie, 2002, vol 22, no 2, pp. 29-32.

3. Khoroshilov S.E., Nikulin A.V., Marukhov A.V. Prevention of the development of multi-organ insufficiency syndrome in the enzymatic phase of severe acute pancreatitis [Preduprezhdenie razvitiia sindroma poliorgannoi nedostatochnosti $\mathrm{v}$ fermentativnoi faze tiazhelogo ostrogo pankreatita]. Bulletin of Pirogov National Medical \& Surgical Center Vestnik Natsional'nogo mediko-khirurgicheskogo tsentra im. N.I. Pirogova, 2014, vol. 9, no 1, pp. 58-62.

4. Rodoman G.V., Shalaeva T.I., Plotkin D.V. et al. Systemic inflammatory response syndrome and the risk for the development of polyorganic insufficiency in patients with acute necrotizing pancreatitis. [Sindrom sistemnoi vospalitel"noi reaktsii i risk razvitiia poliorgannoi nedostatochnosti u patsientov s ostrym nekroticheskim pankreatitom] Bulletin of RSMU - Vestnik Rossiiskogo gosudarstvennogo meditsinskogo universiteta, 2012, no 3, pp. 5-10.

5. Litvin A.A., Khokha V.M., Lur'e V.N. Current trends in surgical treatment of acute necrotizing pancreatitis infected with pancreonecrosis [Sovremennye tendentsii v khirurgicheskom lechenii ostrogo nekrotiziruiushchego pankreatita, infitsirovannogo pankreonekroza]. Novosti Khirurgii Novosti Khirurgii, 2011, no 5, vol. 19, pp. 138-146.

6. Vinnik Iu.S., Dunaevskaia S.S., Antiufrieva D.A. Capabilities of modern methods of imaging acute heavy pancreatitis [Vozmozhnosti sovremennykh metodov vizualizatsii ostrogo tiazhelogo pankreatita]. Novosti Khirurgii - Novosti Khirurgii, 2014, vol. 22, no 1, pp. 58-62.

7. Komolafe O., Pereira S.P., Davidson B.R. et al. Serum C-reactive protein, procalcitonin, and lactate dehydrogenase for the diagnosis of pancreaticnecrosis. Cochrane Database of Systematic Reviews, 2017, no 4, pp. 12645, doi 10.1002/14651858.CD012645.

8. Manohar M., Verma A.K., Venkateshaiah S.U. et al. Pathogenic mechanisms of pancreatitis. World Journal of Gastrointestinal Pharmacology and Therapeutics, 2017, vol. 8, no 1, pp. 10-25, doi 10.4292/wjgpt.v8.i1.10.

9. Diuzheva T.G., Dzhus E.V., Shefer A.V. Configuration of pancreatic necrosis and differential treatment of acute pancreatitis [Konfiguratsiia nekroza podzheludochnoi zhelezy i differentsirovannoe lechenie ostrogo pankreatita]. Annals of HPB Surgery - Annaly khirurgicheskoy gepatologii, 2013, vol. 18, no 1, pp. 92-102. 